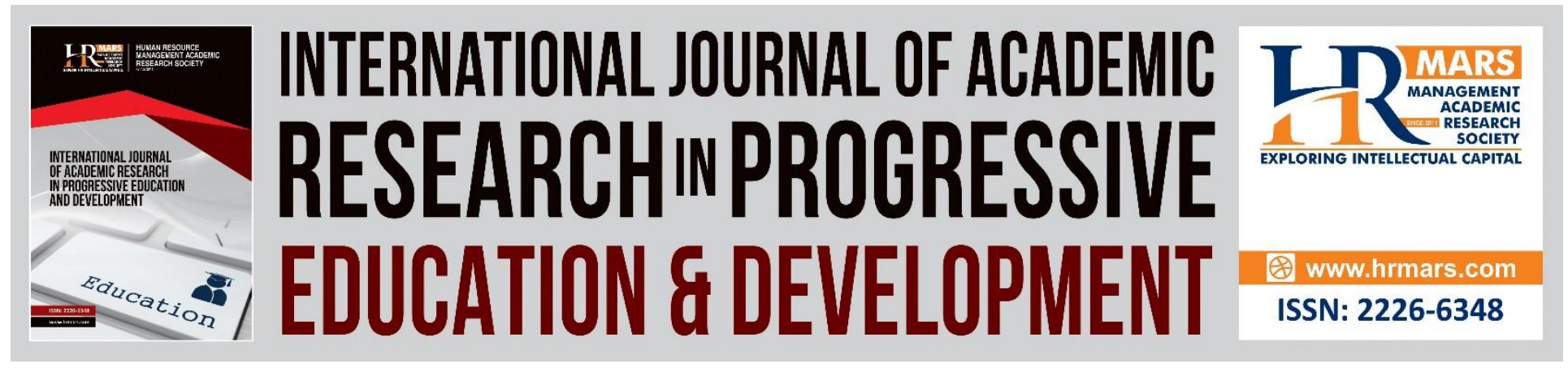

\title{
Can Blended Learning Enhances Student Interest and Understanding in Mathematics?
}

Ruzaihan Jaffar

To Link this Article: http://dx.doi.org/10.6007/IJARPED/v9-i4/8456

DOI:10.6007/IJARPED/v9-i4/8456

Received: 01 October 2020, Revised: 04 November 2020, Accepted: 16 December 2020

Published Online: 26 December 2020

In-Text Citation: (Jaffar, 2020)

To Cite this Article: Jaffar, R. (2020). Can Blended Learning Enhances Student Interest and Understanding in Mathematics? International Journal of Academic Research in Progressive Education and Development, 9(4), 147-163.

Copyright: (C) 2020 The Author(s)

Published by Human Resource Management Academic Research Society (www.hrmars.com)

This article is published under the Creative Commons Attribution (CC BY 4.0) license. Anyone may reproduce, distribute, translate and create derivative works of this article (for both commercial and non-commercial purposes), subject to full attribution to the original publication and authors. The full terms of this license may be seen at: http://creativecommons.org/licences/by/4.0/legalcode

Vol. 9(4) 2020, Pg. 147 - 163

http://hrmars.com/index.php/pages/detail/IJARPED

JOURNAL HOMEPAGE

Full Terms \& Conditions of access and use can be found at http://hrmars.com/index.php/pages/detail/publication-ethics 


\title{
LRE \\ INTERNATIONAL JOURNAL OF ACADEMIC \\ RESEARCHINPROGRESSIVE \\ EDUCATION \& DEVELOPMENT

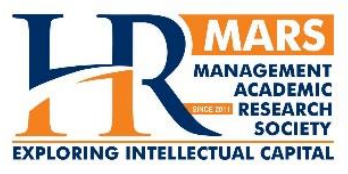 \\ INIERNATIONAL JOURNAL
OF ACADEMIC RESEARCH
IN PROGRESSIVE EDUCATIOH \\ IN PROGRESSIVE EDTCH
AND DEVELOPMENT

 \\ Can Blended Learning Enhances Student Interest and Understanding in Mathematics?
}

\author{
Ruzaihan Jaffar \\ Department of Mathematics, Science \& Computer, Polytechnics of Kuching, Sarawak (PKS), \\ 93050 Kuching, Sarawak, Malaysia.
}

\begin{abstract}
Nowadays, the trend of e-learning is increasing day by day and one of the tools to implement this concept is through Blended Learning (BL). Blended learning (face-to-face plus online learning) is now part of the learning landscape in Higher Education, not just for campus-based courses but also for courses designed for students studying at a distance (Distance Education). The higher education or institutions nowadays are trying to run the fully e-learning concept due to space limitation be it in term of storage or in term of locating the students in the classrooms. This paper focuses on exploring blended learning as an approach to the teaching and learning of mathematics in Polytechnics. Its provide insight and understanding of current and future trends regarding how conventional face-to-face instruction in mathematics is influenced by webbased/computer-supported learning. Practical pedagogical issues related to mathematics and blended learning in Higher Education are also discussed. This research aims to identify the problems faced using e-learning which only cover the scope of looking into student interest in learning and look at the research model that is related and show the findings of the appropriate ways of learning. It is hope through the research model identified, it could guide the educators to find the best way of teaching in TVET institutions.
\end{abstract}

Keywords: Blended Learning, e-learning, Higher Education, Polytechnics, TVET.

\section{Introduction}

The rapid development of technology now requires innovation and transformation in learning. To meet 21st century learning needs, the use of technology in education has been widely used at all levels of education. The evolution of technology has led to the implementation of e-learning in the process teaching and learning (T\&L) face-to-face. The popularity of e-learning on university and other academic campuses has increasing through time to time and the various of distance learning technologies are fully used for teaching method in every courses in institution.

Featuring technology, the development of digital education in Malaysia is one of the few ways to improve the quality of education in Malaysia. According to a report released by Internet World Statistic (2020), the estimated global internet usage statistics as of December 31, 2019 is 4.5 
billion. The rapid growth of global internet users has led to a dynamic pattern of learning. Global quality standards have been the cornerstone of Malaysian education to develop online learning as one of the latest blended learning methods in the 21st century.

Thorne (2003) described blended learning as it represents an opportunity to integrate the innovative and technological advances offered by online learning with the interaction and participation offered in the best of traditional learning.

Graham, Allen, \& Ure (2005) mention three approaches: (a) blended learning as the combination of different instructional methods, (b) blended learning as the combination of different modalities or delivery media, or (c) blended learning as the combination of face-to-face instruction with computer-mediated instruction.

Definition of blended learning by Bersin (2004):

"the combination of different training "media" (technologies, activities, and types of events) to create an optimum training program for a specific audience. The term "blended" means that traditional instructor-led training is being supplemented with other electronic formats. In the context of this book, blended learning programs use many different forms of learning, perhaps complemented with instructor-led training and other live formats".

Measuring the effects of educational methods on learning achievement is a vital aspect of tertiary education. Most educational institutions in Malaysia still practice face-to-face learning rather than using the concept of blended learning (Yazid, 2016).

21st Century learning as a form learning that requires students to master the content and to produce, analyzing and synthesizing, and evaluates information from a wide variety of sources by understanding and respect different cultures (Berry, 2011). Blended Learning is provided by the effective combination of different modes of delivery, models of teaching and styles of learning which are exercised in an interactively meaningful learning environment (Kaur, 2013).

In general terms, blended learning combines the online delivery of educational content with the best features of classroom interaction and live instruction in such a way as to personalize learning, allow thoughtful reflection, and differentiate instruction from student to student across a diverse group of learners.

\section{Problem Statement}

Problems might arise when using e-learning in teaching, students will less focus on the material and it is difficult to retain the student's attention in learning.

One of the e-learning methods, students need to learn through instruction given in the web, but human are still not comfortable to learn without the presence of an instructor. So the lecturers are required to look for any commercially available CD / online learning, bring it to the class and 
ask the students to learn using e-learning method. Lecturer will assist any part of the learning which a limitation to e-learning such as explaining, answering questions or translating (where required) (Ramakrishnan, Yahya, Hasrol, \& Aziz, 2011).

In challenging courses such as mathematics and engineering, struggling students often become frustrated and despondent. The classroom teacher often has little time to assist individual students, and students often have no one at home to turn to for assistance (Lin, Tseng, \& Chiang, 2017).

Another research was done by Azlim \& Jalil (2016) on the performance Engineering Mathematics and lecturer's perceptions in an Engineering student at Polytechnics of Merlimau, Melaka. It found the main factor that leads to failure in Engineering Mathematics which does not do exercise/assignment/tutorial/, there are copying friend's assignment to complete the task, don't know the best method study, bad attitude \& motivation, and weaknesses mathematics foundation.

According to a study conducted by Kasim \& Khalid (2016) on postgraduate students shows that students expect less classes to be held and classroom implementation is evenly done $50 \%$ faceto-face and $50 \%$ more online.

Students' weakness in mastering certain items in English is also one of the reasons students fails in mathematics. Students do not understand the mathematical terms used. A study at the Sultan Idris University of Education (UPSI) conducted by Isahak Haron shows that student achievement results are extremely low in both subjects (Science and Mathematics). Many students find it difficult to use English for T\&L Science and Mathematics. According to Yalani \& Bakar (2017), in Kamaruddin (2002) also noted the decline in language proficiency English among local school and university graduates stems from a phenomenon in which English is not spoken fluently and cannot be well written by university and school students.

\section{Research Objectives}

The objective of this paper is to:

i. To identify the suitable research model describing on methods that shows the motivation in e-learning.

ii. To identify the suitable type of mathematics learning in Malaysian Polytechnics.

\section{Blended Learning in Malaysia Higher Educations}

The Malaysia Education Blueprint 2015 - 2025 (Higher Education) has been launched and ten shifts outline to continue strengthening Malaysia in Higher Education (HE). All 10 Shifts address key performance issues in the system, particularly with regard to quality and efficiency, as well as global trends that are disrupting the higher education landscape. Shifts \#9 is Globalised Online Learning (GOL). GOL focusing on expanding access to education, improving the quality of teaching 
and learning while enabling learning to be tailored to the current needs of students (Dasar ePembelajaran Negara 2.0).

Dasar e-Pembelajaran Negara (DePAN) 2.0 or National e-Learning Policy 2.0 supports the strategic essence of the 10th Malaysia Plan. One of the five strategic thrusts of the $10^{\text {th }}$ Malaysia Plan is to develop world-class human capital by focusing on the 12 national key economic areas (NKEAs), especially in the field of information and communication technology (ICT) and education services.

DePAN 2.0 also specifies that e-Learning unit should be established to oversee the elearning activities at the organization in collaboration with the IT unit.

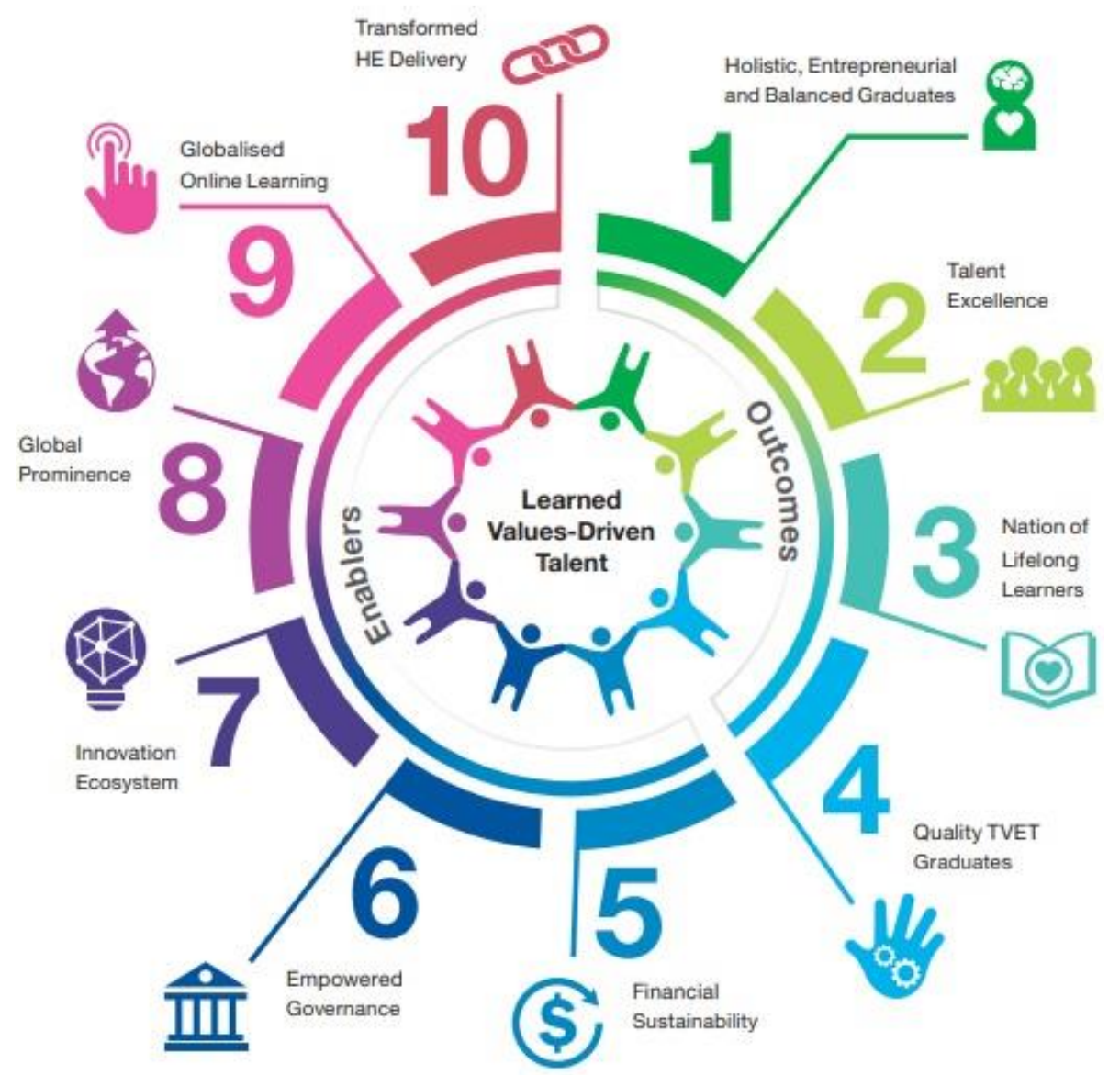

Figure 1. The 10 Shifts Malaysian Education Development Plan (Higher Education) 2015-2025.

There are various shifts to be implemented through the Malaysia Education Blueprint 2013-2025. The plan is designed in the context of increasing our education standards internationally and as a government aspiration in preparing students in our country to cope with the 21st century education challenges. 


\section{Blended Learning in Polytechnics Mathematics Educations}

Blended learning refers to courses that combine a mix of online mode of learning and face-toface learning with $30 \%-80 \%$ of online course content and activities that either support or replace face-to-face learning. The implementation of the blended learning in Malaysian Polytechnics has been since 2014 (Abidin et. al., 2014; CAP eLearning 2014, KPM).

Blended learning is an integration between face-to-face learning and e-learning that enables teaching and learning (T\&L) more competitive (Osman and Hamzah, 2016). To meet the demands and challenges of TVET in Malaysia today, the mastery of student's knowledge in learning should be steady and constantly updated. It is undeniable, mathematics and engineering are inseparable. The success of the practice of blended learning in Malaysian Polytechnics depends on five aspects of pedagogy, faculty, student, institutional: institutional and institutional: organizational aspects (Abidin, et. al., 2014).

There are currently 34 Polytechnics and 92 Community Colleges. Blended learning concept has been practiced in Malaysia Polytechnics since 2014. It focuses on 21st century pedagogy that combines traditional (face-to-face) learning and online learning. The effective of information and multimedia technology is now a tool that can help individuals in the tasks of managing their time, work and daily life.

Meta-analyses have shown that the growing number of students in Higher Education have problems understanding the course content in mathematics, because of their poor knowledge of the subject matter attributed to instructional approaches and learners' perceptions of the learning environment (Lizzio, Wilson \& Simons, 2002). Mathematics is a difficult subject to understand, stressful, and meaningless in life among college students and institutions of higher learning (Idris, 2005). Mathematical learning should aim to discover, apply, and appreciate and cultivate mathematics (May \& Stone, 2010).

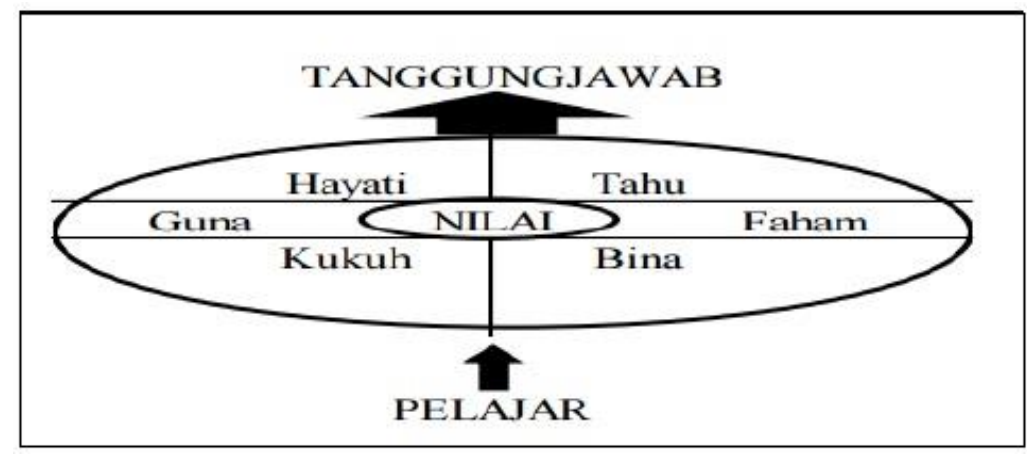

Figure 2. Mathematical Learning Model

(Adaptation from Mathematics Teaching 7P Model, Pa, 2008). 
Mathematics is one of the most important courses for engineering students as it is offered as pre-requisite course to other advanced mathematics or even engineering courses. There are a variety of ways and techniques that can be used in $T \& L$, but no one of the techniques are considered to be the most suitable and the best for all situations or best for all sessions in PdP (Ali, Khalid \& Ghani, 2018).

There are so many studies related to Mathematics education involving either schools or higher education institutions. Said \& Krishnan (2011) said, factors that affecting Mathematics achievement are existing knowledge of mathematics, interests, learning techniques and peer influence. Based on studies by Ramli \& Azis (2016) at Polytechnic Mukah, Sarawak to identify factors that influence students' achievement in Engineering Math course 2 are factors of interest, attitude factor, lecturer and environmental factors.

Allen, Seaman \& Garrett (2007), using the percentages for differentiating between online courses, blended learning courses and face to face (F2F) learning courses. In other words, blended learning endeavours to purposefully and seamlessly integrate online and traditional learning in order to create a distinct, new approach with its own merits (Picciano, 2006)

Table 1. Taxonomic terms related to Blended Learning

\begin{tabular}{|c|c|c|}
\hline $\begin{array}{l}\text { Proportion } \\
\text { of Content } \\
\text { Delivered Online }\end{array}$ & Type of Course & Typical Description \\
\hline $0 \%$ & Traditional & $\begin{array}{l}\text { Course with no online technology used - } \\
\text { content is delivered in writing or orally. }\end{array}$ \\
\hline 1 to $29 \%$ & Web Facilitated & $\begin{array}{l}\text { Course that uses web-based technology to } \\
\text { facilitate what is essentially a face-to-face } \\
\text { course. Uses a course management system } \\
\text { (CMS) or web pages to post the syllabus and } \\
\text { assignments, for example. }\end{array}$ \\
\hline 30 to $79 \%$ & Blended/Hybrid & $\begin{array}{l}\text { Course that blends online and face-to-face } \\
\text { delivery. Substantial proportion of the content } \\
\text { is delivered online, typically uses online } \\
\text { discussions, and typically has some face-to- } \\
\text { face meetings. }\end{array}$ \\
\hline $80+\%$ & Online & $\begin{array}{l}\text { A course where most or all of the content is } \\
\text { delivered online. Typically have no } \\
\text { face-to-face meetings. }\end{array}$ \\
\hline
\end{tabular}

Blended learning is commonly known as student-centered learning with supporting by using of information, communication and multimedia technologies.

\section{Learning Management System (LMS) As Tools in E-learning System}

Curriculum Information Document Online System (CIDOS) is an e-learning system used in polytechnics and community colleges was launched in March 2008 at Putrajaya. CIDOS developed 
Vol. 9, No. 4, 2020, E-ISSN: $2226-6348$ @ 2020 HRMARS

for the use of registered users which includes full curriculum information, polytechnic and community colleges programs study.

All staff and registered learners of the institution are automatically given access to the LMS. The LMS can be accessed on and off-campus using the same user id and password assigned by the The Instructional and Digital Learning Division, JPPKK. LMS user can sign in via url:

http://cidos.edu.my.

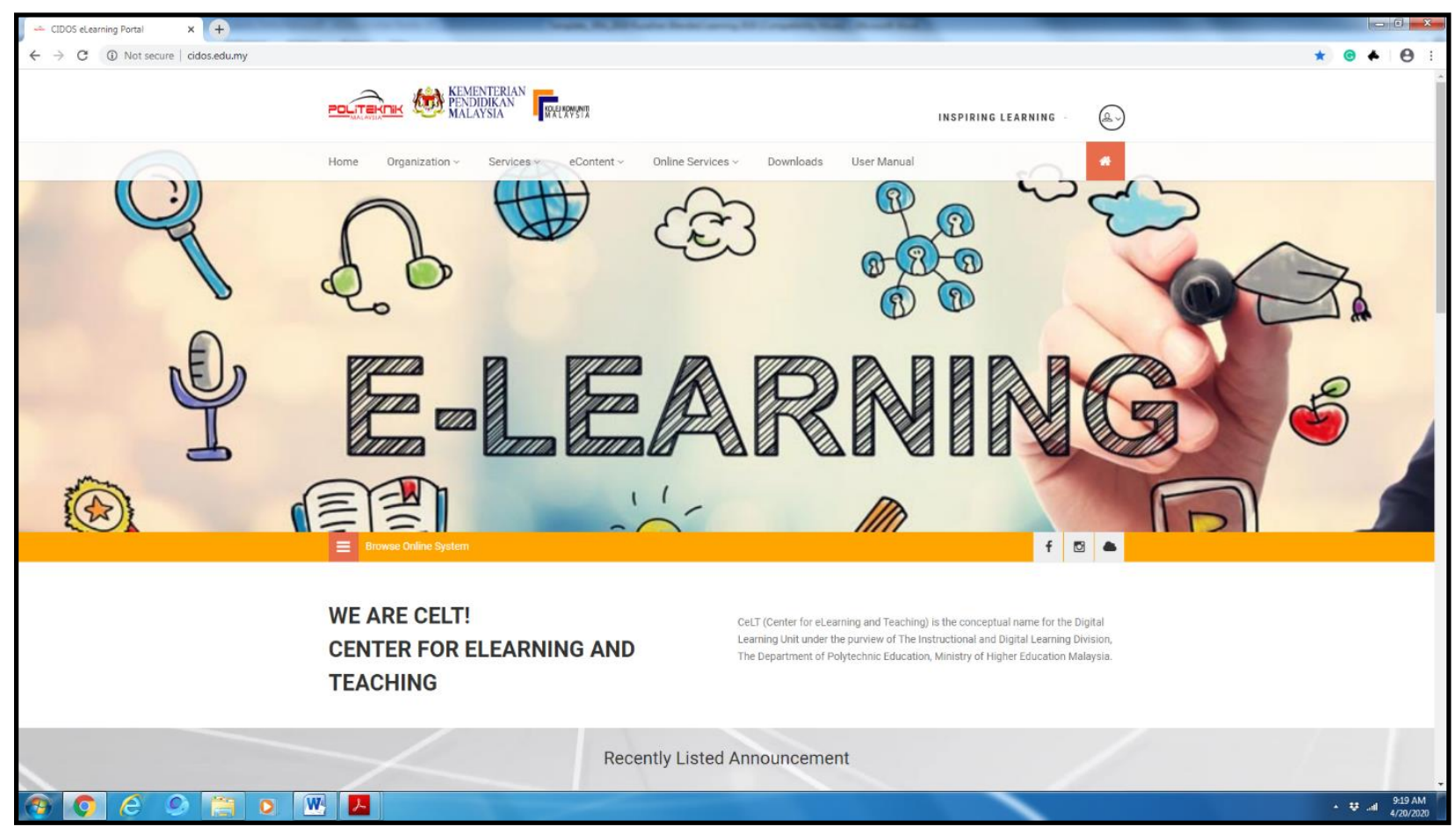

Figure 3. The E-learning system in Malaysian Polytechnics.

These tools are designed with features that blend with the conventional face-to-face classroom and the goals of the courses, as well as, facilitating intensive learning opportunities for the learners.

"Inspiring Learning" - CeLT (Center for eLearning and Teaching) is the conceptual name for the Digital Learning Unit under the purview of The Instructional and Digital Learning Division, The Department of Polytechnic Education, Ministry of Higher Education Malaysia.

CeLT is created to engage and assist the deployment of the eLearning/Blended Learning agenda in all Malaysian Polytechnics. Its headquarters is in Putrajaya, CeLT also has a production studio which is located at Politeknik METrO Kuala Lumpur.

Other examples of e-learning used in developing learning methods are Moodle - Opensourcebased Learning Management System (LMS) [http://moodle.org]. ATutor: Open Content-based 
Learning Content Management System (LCMS) [http://atutor.ca]. Ilmukomputer.com - Free elearning system based on community activity [http://ilmukomputer.com]. A free e-Learning system for students and teachers from Pustekkom Depdiknas [http://e-dukasi.net].

For other TVET institutions in Malaysia, each institution provides an elearning site to allow each student to apply the web. Among them are UTEM - https://ulearn.utem.edu.my, UTHM https://author.uthm.edu.my, UniMaP - http://elearninglab.unimap.edu.my, UMP http://www.ump.edu.my/en/academic/e-learning and Poly-Tech Mara College http://oles.kuptm.edu.my/moodle/

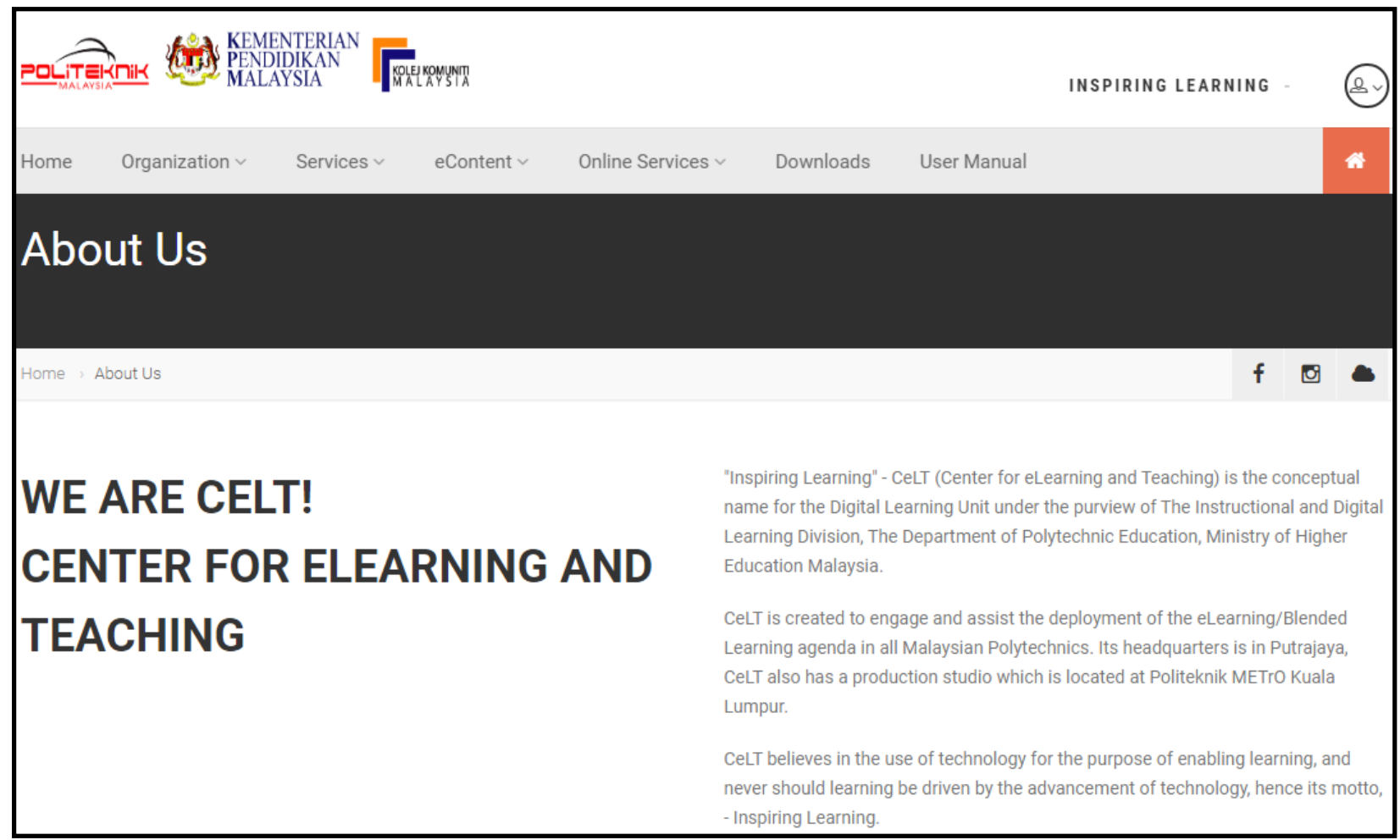

Figure 4. E-learning system in Malaysian Polytechnics developed by CeLT.

LMS is a learning platform designed to provide educators, administrators and learners with a single robust, secure and integrated system to create personalized learning environments. The functions provided by LMS include Dashboard, site announcement, course information, staff information, course documents, assignments, communication, forum, and calendar. E-learning application allows students to communicate directly with each other or with their lecturers via internet services such as e-mail, chat, newsletters and discussions/forums provided. The functions provided by LMS include announcement, course information, staff information, course documents, assignments, communication, discussion board, external links and tools. 


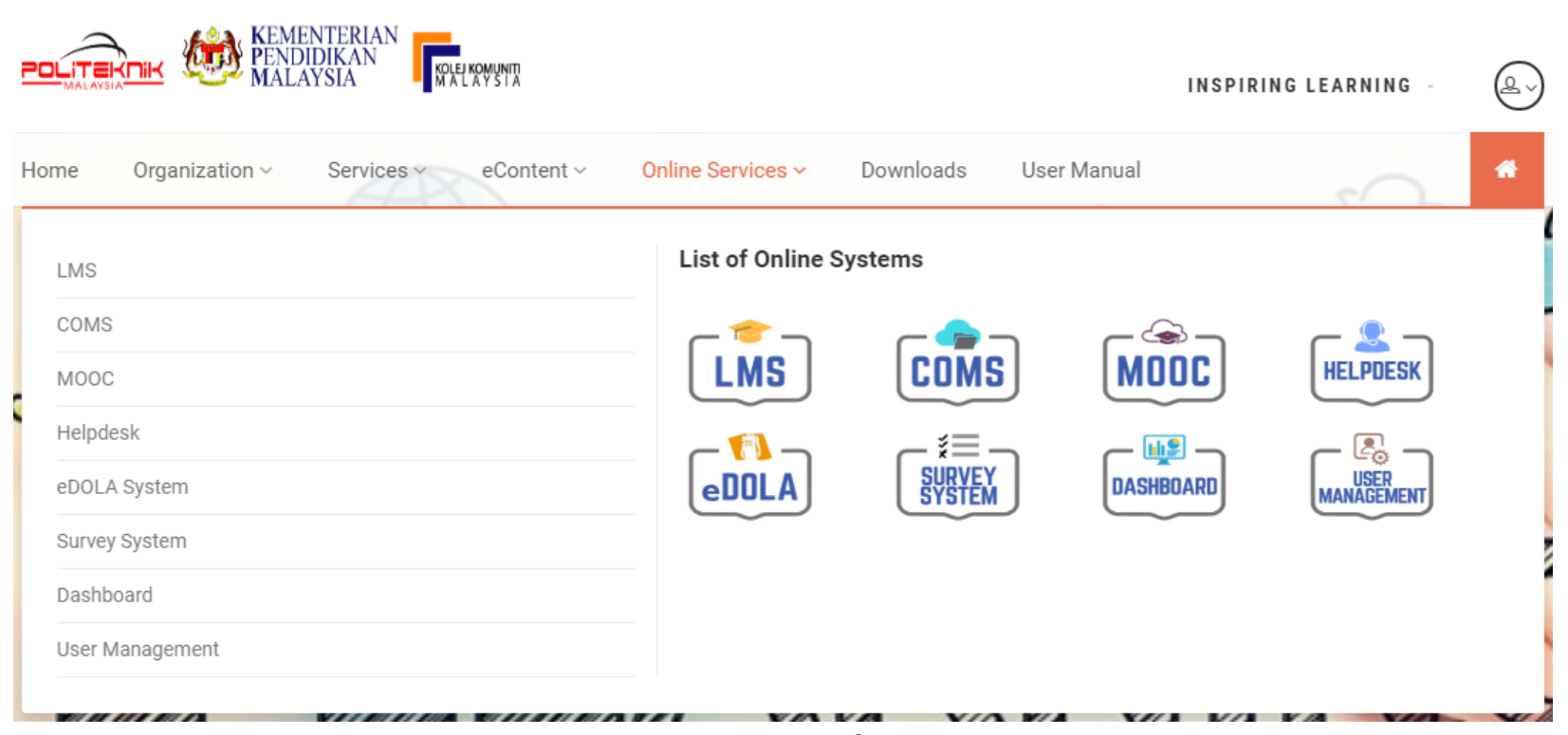

Figure 5. Environment Interface in CIDOS, LMS.

Although students reach a blended level of learning for each subject, they are not yet masterful and knowledgeable about the subject. The importance of learning mathematics for engineering students is to enable them to work with several mathematical ideas and various representations and also use this knowledge in their engineering fields (Baharun, Yusof, \& Rahman, 2007).

Blended learning curriculum in Malaysian Polytechnic contains of several components of learning such as, include Learning Object (LO), e-notes, Collaborative Classroom, e-Contents and Practical. Classroom tasks, Assessments, Computer and web aide, and Strategies were the elements of the model of blended learning mathematics which was used as a guide to classroom instruction.



Figure 6. Blended Learning Component (Abidin, 2014). 
Listed below are the detail description of the categories by Abidin (2014). The categories are:

i. Learning Object (LO) - Complete set of learning that students can learn online. Must be built using specific software with the capability of SCORM (Sharable Content Object Reference Model). LO can be monitored by students through the Learning Management System (LMS) eg. CIDOS.

ii. e-Notes - Lecturer notes that have been reviewed and uploaded to LMS.

iii. e/Collaborative Classroom - the most important component of blended learning is that lecturers can monitor and measure student understanding.

iv. Complementary e-Contents - additional components are expected to enhance student understanding. Demonstrative videos can be developed to help students understand the work process more effectively. This component can be developed in the form of COMPLETE VIDEO, 'PODCAST' etc.

v. Practical - Although the practical component will not be implemented online, it is still an important component in computing the concept of blended learning.

For the purpose of this study the Mathematical Computing course was redesigned and developed in a blended course format (part online, part face-to-face) according to Kerres's \& De Witt's (2003) 3C-model of didactical components in a blended learning arrangement. This model includes three components that need to be taken into account a) a content component that makes learning material available to the learner b) a communication component that offers interpersonal exchange between learners or learners and tutors and c) constructive component that facilitates and guides individual to actively operate on learning tasks (or assignments) with different degrees of

According to Sapari \& Abdullah (2019), five factors that most influence the achievement of Engineering Mathematics 1 are factors of interest, followed by attitude factors, environmental factors, learning style factors and teaching method factors. From the findings, the factors that influence a student's achievement in mathematics are not just from blended learning.

\section{Research Models}

The research model related will discuss the elements used and needed to prove on retaining student interest and understanding the need for e-learning in higher institutions.

Khan, as cited in Singh (2003), proposed a blended learning model. The framework has eight (8) Dimensions: institutional, pedagogical, technological, interface design, evaluation, management, resource support, and ethical (Figure 7). Each dimension in the framework represents a category of issues that need to be addressed. These issues help to organize thinking, and ensure that the resulting learning program creates a meaningful learning experience.

Khan's framework as stated in the article on Blended learning serves as a guide to plan, develop, deliver, manage, and evaluate blended learning programs. Organizations exploring strategies for effective learning and performance have to consider a variety of issues to ensure effective 
INTERNATIONAL JOURNAL OF ACADEMIC RESEARCH IN PROGRESSIVE EDUCATION AND DEVELOPMENT

Vol. 9, No. 4, 2020, E-ISSN: $2226-6348$ @ 2020 HRMARS

delivery of learning and thus a high return on investment. Today a blended learning program may combine one or more of the following dimensions, although many of these have over-lapping attributes.

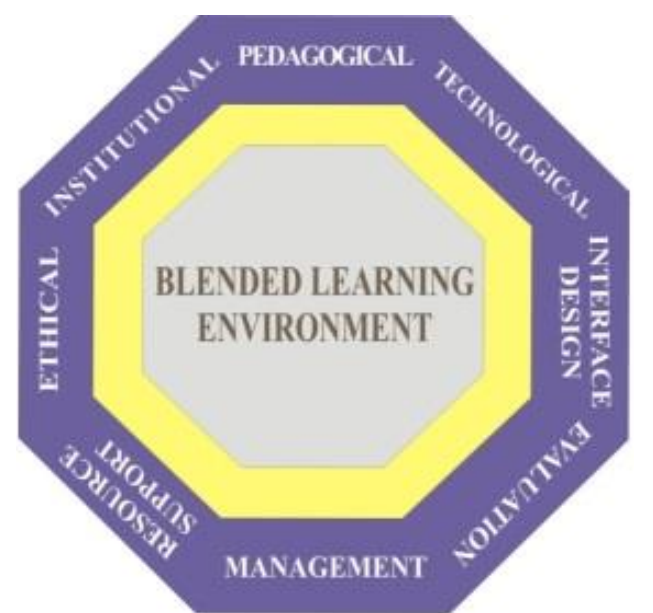

Figure 7. Diagrams Khan's Octagonal Blended Learning Model.

\section{End User Training (EUT)}

The framework summarizes the EUT research is shown in Figure 4. According to Gupta (2003), training methods refers to the method by which participants learn. Learning techniques related to specific procedures will be used in the training method.



Figure 8. EUT Model (Gupta, Bostrom \& Huber, 2006). 
INTERNATIONAL JOURNAL OF ACADEMIC RESEARCH IN PROGRESSIVE EDUCATION AND

DEVELOPMENT

Vol. 9, No. 4, 2020, E-ISSN: $2226-6348$ @ 2020 HRMARS

\section{Conceptual Framework on Learning Barrier}

Packham (2004) stated that if the control mechanisms of an e-learning programme are efficient and effective then they will act as enabling mechanisms that enhance the learning experience and hence, improve retention.

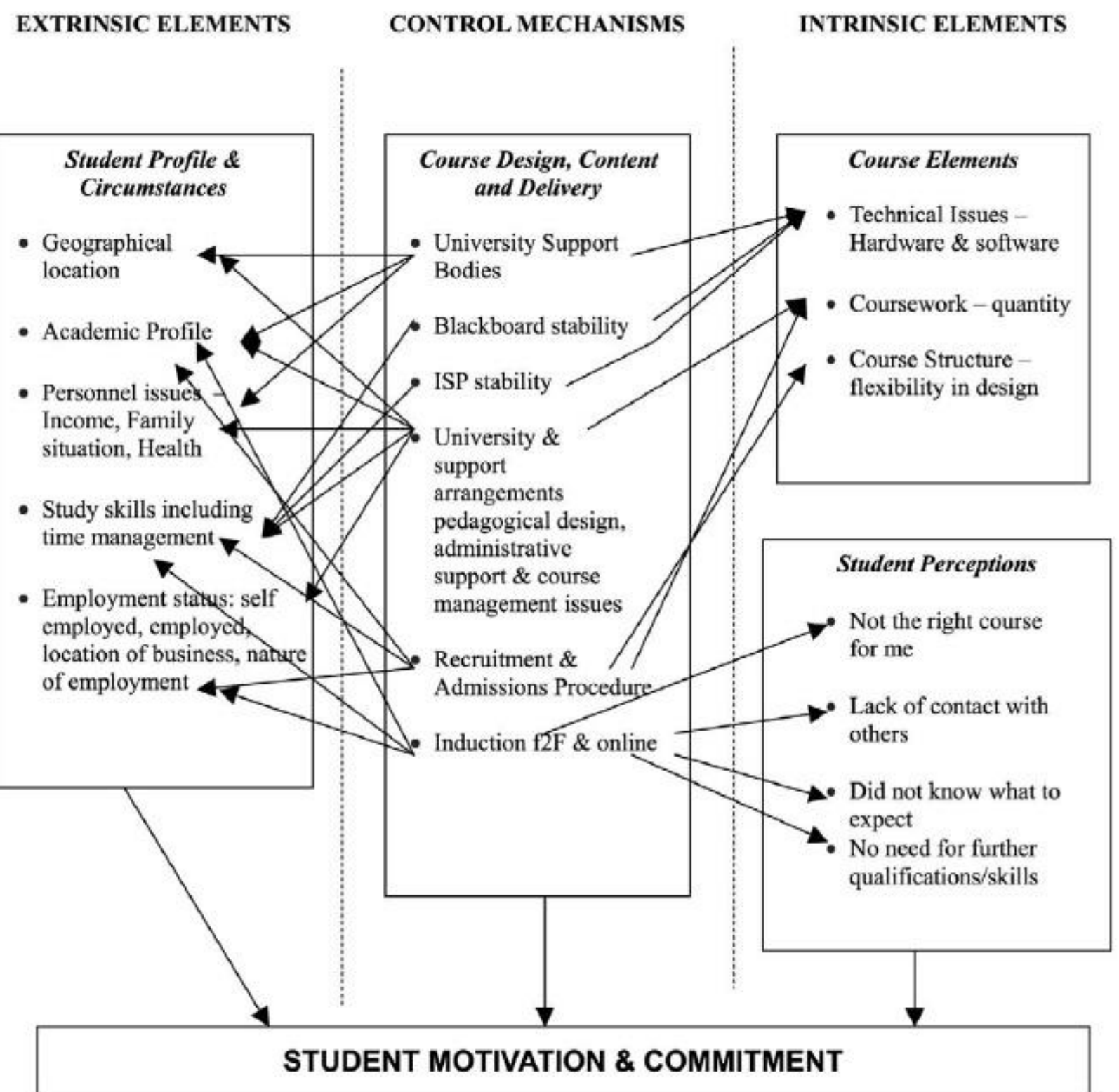

Figure 9. A conceptual framework for the classification of barriers to learning on an online programme.

\section{Method}

The methods of obtaining data in this research include several steps and involve secondary methods, which is the document review. The steps include (1) identify the areas, (2) list the terms and explanation through reading the literature and documents, (3) Identify the related research 
model, (4) Analyzed the documents and do the research finding (5) Writing the reports. The detail description of the steps will be elaborate below. The steps, shown in Figure 8, will show the steps of the research methods for this research paper.

- Area Identification

- Literature Review

- Research model identification

- Research finding

- Report writing

Figure 10. Diagrams the flow of Research Method.

\section{Analysis and Findings}

This section will look into detail the three research model and map out with the problems identified in the first section. There are various problems could be found in using e-learning. One of the challenge faces by higher education mentioned by Tucker \& Gentry (2009) is the Steep budget cuts, which include layoffs, frozen enrollments, and hiring freezes have overburdened teaching and learning in higher education. But this paper will focus on the students in higher education using e-learning and it is hope that it could gain the interest in learning. Through EUT framework that is illustrated in Figure 8 in previous section, that the learning and interaction process is influenced by the training methods which consist of the learning techniques and the technology used. The learning techniques and the technology used must be parallel. But it does not just depend on the technology but it also depends on the individual differences and the support given on it. The result of the e-learning also can be affected solely through this individual difference.

The framework illustrated by Packham (2004) tells that student motivation and commitment is affected by not just the control mechanism, which is the technology itself but also affected by the factors on extrinsic and intrinsic mechanism. The extrinsic factors refer to the student profile and skill, while an intrinsic element is related with the students course elements and the perception towards the e-learning. While blended learning shows that learning style, requirements and preferences are different. Khan mentioned that organizations must use a blend of learning approaches in their strategies to get the right content in the right format to the right people at the right time. Blended learning combines multiple delivery media that are designed to complement each other and promote learning and application-learned behavior.

\section{Conclusion}

As discussed earlier, many studies have indicated that the blended learning method has positive impacts on learning outcomes. For instance, Wiginton (2013), Demirkolb \& Kazu (2014), Abdul \& Aris (2016) have found that the blended learning method is more effective in terms of academic 
achievement than traditional methods. The emergence of technologies and variety of applications has made teaching and learning of mathematics a dynamic process. Blended learning courses are being offered at different higher institutions through the use of LMS. This study has outlined the concept of the blended learning approach from the perspective of mathematics in Malaysian Polytechnics. Diversity in learning methods can also enhance academic performance in mathematics education is also discussed. This study can be considered as a proactive prospect to make Malaysian Polytechnic a higher level in adopting a mixed learning approach. Thus all available technology facilities can be used as learning opportunities. It may also enable a lecturer in mathematics to select a suitable blended learning environment for teaching and learning programs in mathematics.

\section{Acknowledgement}

To begin with, my utmost thanks and gratitude goes to Polytechnics of Kuching Sarawak, my Director Mdm. Jamaliah Ahmad for imparting me with her wealth of knowledge, valuable guidance and experience. My appreciation and thanks is also dedicated to Outcome-Based Education (OBE) unit for their helpful insights, cooperation and stimulating comments. I would also like to express my apology for any mistake and shortcoming in carrying out this task. To end with, I am truly delighted, for this research would bring benefits to others.

\section{References}

Abdul, H. F. H., \& Aris, N. S. (2016). Persepsi Pelajar Terhadap Pembelajaran Teradun (Blended Learning). Journal of Technical and Vocational Education, 1(2), 53-63.

Abidin, Z. Z. A., Kassim, S., Tan, M. E., Hilim, N., Ahmad, N., Sahat, H., M. Zain, N. F., \& Omar, N. S., (2014). Garis Panduan Amalan Terbaik Konsep Pembelajaran Teradun Bagi PoliteknikPoliteknik Malaysia. Jabatan Pengajian Politeknik. Retrieved from http://www.poliku.edu.my/wp-content/uploads/2019/09/Bleanded_learning.pdf

Ahmad, S. S., \& Othman, N. (2014). Matematik dan Disseminasi Ilmu: Tinjauan Persepsi Pelajar Pengurusan. Proceeding of the 1st International Conference on Management and Muamalah, 220-225.

Allen, I. E., Seaman, J., \& Garrett, R. (2007). Blending in The Extent and Promise of Blended Education in the United States. United States of America: The Sloan Consortium.

Ali, S. F., Khalid, K. N. L., \& Ghani, A. T. W. (2018). Abad 21: Trend Pembelajaran dan Pengajaran Politeknik \& Kolej Komuniti Malaysia. Putrajaya: JPPKK.

Azlim, N. D. H., \& Jalil, A. E.D. (2016). Poor Foundation in Differentiation and Integration Leads to Student Failure in Engineering Mathematics. 6st National Conference in Education Technical and Vocational in Education and Training. 1, 364-372.

Baharun, S., Yusof, M. Y., \& Rahman, A. R. (2007). Enhancing Engineering Students' Mathematical Competency Through Mathematical Thinking. Conference: Third International Conference on Research and Education on Mathematics 2007 (ICREM07), Kuala Lumpur Malaysia.

Berry, B. (2011). Teaching 2030: What we must do for our students and our public schools. Now and in the Future. North Carolina: Teachers College Press.

Bersin, J. (2004). The Blended Beaming Book: Best Practices, Proven Methodologies, and Lessons Learned. San Francisco: Pfeiffer Publishing. 
Demirkolb, M., \& Kazu, I. Y., (2014). Effect of Blended Learning Environment Model On High School. The Turkish Online Journal of Educational Technology - January 2014, 13 (1), 10.

Graham, C. R., Allen, S., \& Ure, D. (2005). Benefits and challenges of blended learning environments. Encyclopedia of Information Science and Technology, 253-259. from: Encyclopedia of Information Science and Technology, First Edition.

Gupta, S., Bostrom, P., \& Huber, M. (2006) End-User Training Methods: What We Know, Need to Know Retrieved from https://dl.acm.org/doi/abs/10.1145/1899639.1899641

Idris, N. (2005). Pedagogi Dalam Pendidikan Matematik. Kuala Lumpur: Utusan Publications.

Internet World Statistic. (2020). Retrieved from https://www.internetworldstats.com/stats.htm

Kamaruddin, I. F. (2002). USM Usaha Hasilkan Siswazah Berkualiti. Berita USM. https://www.usm.my/bi/berita-penuh-en.asp?id=7550\&idform $=7$

Kasim, M. N. N., \& Khalid, F. (2016) "Kesesuaian Pembelajaran Teradun Dari Sudut Pandangan Pelajar Pascasiswazah". International Conference on Education for Sustainable Regional Development 2016. http://icerd2016.conference.upi.edu/wp-

Kaur, M. (2013). Blended learning-its challenges and future. Procedia-Social and Behavioral Sciences 93 (2013), 612-617.

Kerres, M., \& Witt, C. W. (2003). A didactical framework for the design of blended learning arrangements. Journal of Educational Media, 28(2/3),101-113.

Lin, Y. W., Tseng, C. L., \& Chiang, P. J. (2017). The Effect of Blended Learning in Mathematics Course. A Journal of Mathematics Science and Technology Education, 13 (3), 741-770.

Lizzio, A., Wilson, K., \& Simons, R. (2002). University students' perceptions of to the learning environment and academic outcomes: Implication for theory and practice. Studies in Higher Education, 27(1), 27-52. DOI: 10.1080/03075070120099359

May, A. L., \& Stone, C. A. (2010). Stereotypes of Individuals with Learning Disabilities: Views of College Students with and without Learning Disabilities. Journal of Learning Disabilities 43(6), 483-499.

Osman, N., \& Hamzah, M. I. (2014). Hubungan Kesediaan Pelajar Mengikuti Pembelajaran Berasaskan Blended Learning Berdasarkan Jantina dan Program. Universiti Sultan Zainal Abidin, Universiti Kebangsaan Malaysia. Jurnal Kurikulum \& Pengajaran Asia Pasifik 2016.

Pa, N. N. A. (2008). Penyelidikan Tentang Nilai Dalam Pendidikan Matematik Dan Sains: Di Mana Dan Ke Mana? Seminar Kebangsaan tentang Nilai dalam Pendidikan Matematik dan Sains. Anjuran Universiti Malaya, Kuala Lumpur.

Packham, G. (2004). E-learning and retention: key factors influencing student withdrawal. Retrieved March 2020 from www.emeraldinsight.com/10.1108/00400910410555240

Pelan Pembangunan Pendidikan Malaysia (Pengajian Tinggi), (2015). Kementerian Pendidikan Malaysia. Retrieved from http://mohe.gov.my/muat-turun/awam/penerbitan/pppm2015-2025-pt/3-pelan-pembangunan-pendidikan-malaysia-2015-2025-pendidikan-tinggi

Picciano, A. G. (2006), Blended learning: Implications for growth and access. Journal of Asynchronous Learning Networks, 10(3), 95-102.

Ramakrishnan, P., Yahya, Y., Hasrol, M. N., \& Aziz, A. A. (2012), Blended Learning: A Suitable Framework for E-Learning in Higher Education. The 3rd International Conference On eLearning ICEL2011, 23-24 November, Bandung, Indonesia. 
Ramli, S., \& Azis, I. N. D. (2016). Faktor - Faktor Yang Mempengaruhi Pencapaian Pelajar Dalam Kursus Matematik Kejuruteraan 2 (DBM 2013) Di Politeknik Mukah. Technology and Innovation (TECHON) 2016 National Conference. 2, 145-154.

Said, M. N. H., \& Krishnan, J. (2011). Faktor-Faktor Yang Mempengaruhi Penggunaan EPembelajaran Di Kalangan Pelajar Tahun Akhir Jabatan Multimedia (SPK, SPT,dan SPP) Fakulti Pendidikan, Universiti Teknologi Malaysia, Universiti Teknologi Malaysia. International Malaysian Educational Technology Convention.

Sapari, J., \& Abdullah, A. H. (2019). Faktor-Faktor Yang Mempengaruhi Pencapaian Kursus Matematik Kejuruteraan 1 Dalam Kalangan Pelajar Politeknik di Johor. Isu-isu Pendidikan Kontemperari. Malaysia: UTM.

Singh, H. (2003). Building effective blended learning program. Educational Technology, 43(6), 5154.

Thorne, K. (2003). Blended Learning: How to integrate online \& traditional learning. London: Kagan Page Limited.

Tucker, J., \& Gentry, G. (2009). Developing an e-learning strategy in higher education.

Retrieved from https://www.researchgate.net/publication/235298347_Developing_an_elearning_strategy_in_higher_education

Vernadakis, N., Giannousi, M., Derri, V., \& Michalopoulos, M. (2012). The impact of blended and traditional instruction in students' performance. Procedia Technology. 1, 439-443.

Wiginton, B. L. (2013). Flipped instruction: An investigation into the effect of learning environment on student self-efficacy, learning style, and academic achievement in an algebra I classroom (Unpublished doctoral dissertation). University of Alabama, Tuscaloosa, AL.

Yalani, N. N., \& Bakar, N. R. (2017). The English Proficiency and Internal and External Factors Affected It's Among IPTS Student in Selangor. Malaysian Online Journal of Education. 1, 20-28.

Yazid, N. A. (2016). Amalan Pembelajaran Teradun Pensyarah Di Politeknik Sultan Salahuddin Abdul Aziz Shah. Report of Master Project. Malaysia: UTHM. 